\title{
THE EFFECT OF HYDROLYZED VIRGIN COCONUT OIL ON LIPID PROFILE AND LIVER ENZYMES IN DYSLIPIDEMIC RATS
}

\author{
LINDA MARGATA ${ }^{1}$, JANSEN SILALAHI $^{1 *}$, URIP HARAHAP $^{2}$, DENNY SATRIA ${ }^{3}$ \\ ${ }^{1}$ Department of Pharmaceutical Chemistry, Faculty of Pharmacy, Universitas Sumatera Utara, Medan, Indonesia. ${ }^{2}$ Department of \\ Pharmacology, Faculty of Pharmacy, Universitas Sumatera Utara, Medan, Indonesia. ${ }^{3}$ Department of Pharmaceutical Biology, Faculty of \\ Pharmacy, Universitas Sumatera Utara, Medan, Indonesia. Email: jansen@usu.ac.id
}

Received: 22 May 2018, Revised and Accepted: 26 June 2018

ABSTRACT

Objective: The objective of this study was to investigate the effect of virgin coconut oil (VCO) and hydrolyzed VCO (HVCO) on lipid profile and liver enzymes in dyslipidemic rats.

Methods: VCO was hydrolyzed using lipase from Rhizomucor miehei (active on sn-1,3 position). Thirty male rats (150-200 g) were induced with $2 \mathrm{ml} / \mathrm{kg}$ body weight (BW) egg yolk and lard oil twice a day for 30 days. Rats were divided into six groups which were given with sodium carboxymethylcellulose 0.5\%, atorvastatin, VCO (4 and $6 \mathrm{ml} / \mathrm{kg} \mathrm{BW}$ ), and HVCO (4 and $6 \mathrm{ml} / \mathrm{kg}$ BW). Lipid profile including total cholesterol (TC), triglyceride (TG), low-density lipoprotein cholesterol (LDL-C), high-density lipoprotein cholesterol (HDL-C), very low-density lipoprotein cholesterol (VLDL-C), and liver enzymes including serum glutamic oxaloacetic transaminase (SGOT) and serum glutamic pyruvic transaminase (SGPT) were measured after 14 days of treatment.

Results: The results of this study show that VCO and HVCO improve lipid profile (decrease in TC, TG, LDL-C, and VLDL-C, but increase in HDL-C). VCO and HVCO also lower atherogenic index, TC/HDL-C ratio, LDL-C/HDL-C ratio, SGOT, and SGPT. Result shows that HVCO improves lipid profile and liver enzymes better than VCO does.

Conclusion: VCO and HVCO improve lipid profile in dyslipidemic rats, not atherogenic, and not toxic to the liver. HVCO causes better lipid profile improvement, especially with $6 \mathrm{ml} / \mathrm{kg}$ BW dosage.

Keywords: Virgin coconut oil, Hydrolyzed virgin coconut oil, Enzymatic hydrolysis, Dyslipidemia, Lipid profile, Liver enzymes

(C) 2018 The Authors. Published by Innovare Academic Sciences Pvt Ltd. This is an open access article under the CC BY license (http://creativecommons. org/licenses/by/4. 0/) DOI: http://dx.doi.org/10.22159/ajpcr.2018.v11i10.27476

\section{INTRODUCTION}

Virgin coconut oil (VCO) is a high-quality product from the coconut tree and one of mainstay products in tropical countries. Basically, there are two kinds of coconut oil: VCO and typical coconut oil (refined, bleached, and deodorized/RBD oil). Both VCO and RBD oils contain a beneficial fatty acid which is medium chain fatty acid (MCFA), but VCO has another beneficial effect because of its natural manufacturing process, and hence, it still contains large amount of phytonutrients $[1,2]$.

In 1953-1957, based on his studies, Ancel Keys gave statements about the atherogenicity of fats. He stated that saturated fats, including coconut oil, could increase total cholesterol (TC) while unsaturated fats decrease TC. In 1960s, unsaturated fat industries in the United States took advantage of these statements to promote their products. Not until 1990s, negative perspective on coconut oil was cleared because formerly it had not been known that coconut oil is different from other saturated fats $[2,3]$.

VCO is composed mainly of medium chain triglyceride (MCT). In the body, MCT and long-chain triglyceride (LCT) are metabolized differently. MCT is hydrolyzed in the mouth and stomach by lingual lipase and gastric lipase, respectively. The hydrolyzed form of MCT which is 2-monoacylglycerol and MCFA is rapidly absorbed by the enterocytes into the portal vein and then directly enters the liver to be metabolized into energy, and hence, MCT does not increase blood triglyceride (TG). On the other hand, LCT is not digested in the mouth and stomach. LCT should first be emulsified by bile acid and then hydrolyzed by lipase in the intestine (pancreatic lipase), absorbed by the enterocytes, and undergo resynthesis into new TGs. The new TGs enter the lymph system as chylomicrons which then transported into the heart and circulation, and hence, LCT increases blood TG. Due to its rapid metabolism, MCT oils are beneficial in preventing and treating obesity. MCT oil unique physicochemical properties are also known to be beneficial for improving health condition in general and lipid profile in particular [4-8]

Studies about the effect of VCO on cardiovascular disease prevention and treatment have been reported in several studies [9-14]. However, the study about VCO and its enzymatic hydrolysis on cardiovascular disease prevention and treatment has not been reported yet. The objective of this study was to evaluate the beneficial effect of VCO and its enzymatic hydrolysis on serum lipid profiles and liver enzymes in dyslipidemia-induced rats.

\section{MATERIALS AND METHODS}

\section{Materials}

VCO (Palem Mustika ${ }^{\circledR}$, Indonesia) was procured from the local market. All chemicals and reagents used in this work were of analytical grade unless otherwise stated. Tris $\mathrm{HCl}$ (molecular biology grade) was purchased from Vivantis Inc., USA. Sodium hydroxide, sodium sulfate anhydrous, and sodium carboxymethylcellulose were the products of Merck, Germany. Distilled water was purchased from Bratachem, Indonesia. n-Hexane was obtained from Macron Chemicals, USA. Lipase from Rhizomucor miehei (>20000 U/g; Cat. No: L4277) was purchased from Sigma-Aldrich, USA. Lard oil and quail egg yolk used to induce dyslipidemia in rats were obtained from the local market. Atorvastatin $20 \mathrm{mg}$ tablets were purchased from the local pharmacy. 


\section{Enzymatic hydrolysis of VCO}

About $30 \mathrm{~g}$ of oil was weighed into $250 \mathrm{ml}$ Erlenmeyer flask, and then $30 \mathrm{ml}$ distilled water, $12.5 \mathrm{ml} 0.063 \mathrm{M} \mathrm{CaCl}_{2}, 25 \mathrm{ml}$ buffer Tris-HCl 1 $\mathrm{M} \mathrm{pH} 8$, and $3 \mathrm{ml}$ lipase from $R$. miehei were added into the flask. The mixture was incubated at $50^{\circ} \mathrm{C}$ and stirred at $200 \mathrm{rpm}$ for $10 \mathrm{~min}$ of every $1 \mathrm{~h}$ incubation time $(10 \mathrm{~h})$. At the end of incubation time, the mixture was transferred into the separating funnel, then $50 \mathrm{ml}$ $\mathrm{n}$-hexane was added, and extraction was done. The mixture was allowed to stand for some time until two layers were formed. The upper layer (n-hexane fraction) was separated as the first filtrate, while the bottom layer (water fraction) was extracted again with $50 \mathrm{ml}$ of n-hexane. The mixture was then allowed to stand for some time and the upper layer formed was separated as the second filtrate. The first and second filtrates were mixed, and then $250 \mathrm{~g}$ sodium sulfate anhydrous was added to absorb the water residue. The combined filtrate was allowed to stand for $15 \mathrm{~min}$, filtered, and the $\mathrm{n}$-hexane was evaporated using the water bath to obtain hydrolyzed VCO (HVCO) [15-19].

\section{Experimental design}

The experiment was carried out on 30 male rats, weighing approximately $150-200$ g. Rats were housed in an air-conditioned room at $22-25^{\circ} \mathrm{C}$, under 12-light/dark cycle, fed on basal diet and tap water ad libitum. Animals fed on a basal diet for 1 week acclimatization before starting the experiment. The protocol was approved by the Animal Research Ethics Committees of the Faculty of Mathematics and Natural Sciences, Universitas Sumatera Utara, Indonesia (bearing number: 881/KEPHFMIPA/2016). After acclimatization period, rats were fasted for $18 \mathrm{~h}$ and blood TC was measured using strip test. Then, rats were given with $2 \mathrm{ml} / \mathrm{kg}$ BW quail egg yolk and lard oil twice a day. After 30 days of induction, blood TC of each rats was measured and rats with TC higher than $200 \mathrm{mg} / \mathrm{dl}$ were used for the test $[20,21]$.

Rats were divided into six groups (five animals each) and were given: (1) Distilled water (control group), (2) $10 \mathrm{mg} / \mathrm{kg} \mathrm{BW}$ of atorvastatin, (3) $4 \mathrm{ml} / \mathrm{kg} \mathrm{BW}$ of VCO, (4) $6 \mathrm{ml} / \mathrm{kg}$ BW of VCO, (5) $4 \mathrm{ml} / \mathrm{kg} \mathrm{BW}$ of HVCO, and (6) $6 \mathrm{ml} / \mathrm{kg} \mathrm{BW}$ of HVCO, for 14 days. After the end of treatment, rats were fasted for $18 \mathrm{~h}$ and anesthetized with $70 \mathrm{mg} / \mathrm{kg}$ BW of ketamine intraperitoneally. Blood was collected directly from the heart and centrifuged for $10 \mathrm{~min}$ at $3000 \mathrm{rpm}$ to obtain serum. Serum collected was then analyzed for lipid profile (TC, TG, and high-density lipoprotein cholesterol [HDL-C]) and liver enzymes including serum glutamic oxaloacetic transaminase (SGOT) and serum glutamic pyruvic transaminase (SGPT). Low-density lipoprotein cholesterol (LDL-C), very low-density lipoprotein cholesterol (VLDL-C), atherogenic index (AI), TC/HDL-C ratio, and LDL-C/HDL-C ratio were calculated using these following equations [12,21-23]:

$$
\begin{gathered}
\mathrm{LDL}-\mathrm{C}=\mathrm{TC}-\frac{\text { Triglyceride }}{5}-(\mathrm{HDL}-\mathrm{C}) \\
\mathrm{VLDL}-\mathrm{C}=\frac{\text { Triglyceride }}{5} \\
\mathrm{AI}=\frac{(\mathrm{TC}-\mathrm{HDL}-\mathrm{C})}{\mathrm{HDL}-\mathrm{C}} \\
\mathrm{TC} / \mathrm{HDL}-\mathrm{Cratio}=\frac{\mathrm{TC}}{\mathrm{HDL}-\mathrm{C}} \\
\mathrm{LDL}-\mathrm{C} / \mathrm{HDL}-\mathrm{Cratio}=\frac{\mathrm{LDL}-\mathrm{C}}{\mathrm{HDL}-\mathrm{C}}
\end{gathered}
$$

\section{Statistical analysis}

All data were statistically analyzed using one-way ANOVA followed by Tukey's test using computerized SPSS package program (SPSS 17.0 software for Windows). Results are expressed as mean \pm standard error and considered significantly different at $\mathrm{p}<0.05$.

\section{RESULTS}

\section{Blood TC before and after treatment}

After dyslipidemia induction, rats were given with tested oils for 14 days. The effect of VCO and HVCO on blood TC before induction, after induction (before treatment), and after 14 days treatment and the mean of TC decrease are shown in Table 1.

From Table 1, it is shown that TC level in all the groups decreases during the treatment. The lowest TC decrease is in rats given with distilled water (control group) which is $36.8 \mathrm{mg} / \mathrm{dl}$, while the highest TC decrease is in rats given with atorvastatin $10 \mathrm{mg} / \mathrm{kg} \mathrm{BW}$ and HVCO $6 \mathrm{mg} / \mathrm{kg}$ BW. TC decrease in rats given with atorvastatin and HVCO $6 \mathrm{ml} / \mathrm{kg} \mathrm{BW}$ is not significantly different which are $223.8 \mathrm{mg} / \mathrm{dl}$ and $223.2 \mathrm{mg} / \mathrm{dl}$, respectively.

\section{Effect on lipid profile after 14 days of treatment}

The effect of VCO and HVCO on lipid profile in dyslipidemic rats after 14 days of treatment is presented in Table 2 .

In Table 2, it is shown that rats fed with distilled water have the highest TC, TG, LDL-C, and VLDL-C level and the lowest HDL-C level, while VCO and HVCO (both 4 and $6 \mathrm{ml} / \mathrm{kg} \mathrm{BW}$ ) show the otherwise. The results in this study also show that TG, LDL-C, and VLDL-C levels in rats fed with $6 \mathrm{ml} / \mathrm{kg}$ BW HVCO and $10 \mathrm{mg} / \mathrm{kg} \mathrm{BW}$ atorvastatin are not significantly different ( $p>0.05)$, while the TC and HDL-C in both groups are significantly different $(\mathrm{p}<0.05)$.

\section{Effect on AI, TC/HDL-C ratio, and LDL-C/HDL-C ratio}

The effect of VCO and HVCO on AI, TC/HDL-C ratio, and LDL-C/HDL-C ratio on dyslipidemic rats is shown in Table 3.

Table 3 shows that rats fed with distilled water have the highest AI, while AI in rats fed with atorvastatin, $\mathrm{VCO}$, and $\mathrm{HVCO}$ is not significantly different. It is shown that rats fed with $6 \mathrm{ml} / \mathrm{kg} \mathrm{BW} \mathrm{HVCO}$ has the lowest AI which is 0.97 . This value does not differ significantly with the group fed with atorvastatin which is 1.62 . The highest TC/HDL-C ratio and LDL-C/HDL-C ratio in this study are the groups fed with distilled water which are 9.00 and 7.12, respectively, while the lowest TC/HDL-C and LDL-C/HDL-C ratios are the groups fed with $6 \mathrm{ml} / \mathrm{kg}$ BW HVCO which are 1.98 and 0.74 , respectively.

\section{Effect on liver enzymes}

The effect of VCO and HVCO on liver enzymes (SGOT and SGPT) in dyslipidemic rats is shown in Table 4.

From Table 4, it is shown that liver enzymes (SGOT and SGPT) in rats fed with atorvastatin, VCO, and HVCO are significantly lower than rats fed with distilled water

\section{DISCUSSION}

In this study, rats were given with quail egg yolk and lard oil to induce dyslipidemia. Blood TC was shown to increase after induction for 30 days. This is due to the high cholesterol content in quail egg yolk and saturated fats in lard oil. Egg, especially from the bird species, was one of the protein sources that has high nutrition value and functional properties. However, too much consumption of egg would cause health problem such as coronary heart disease due to its high cholesterol content in the yolk. Quail egg yolk has been shown to have a very high cholesterol content. Aziz et al. (2012) reported that the average cholesterol content in chicken, duck, and quail eggs was $7.65 \mathrm{mg} / \mathrm{g}$ yolk, $10.36 \mathrm{mg} / \mathrm{g}$ yolk, was $16.05 \mathrm{mg} / \mathrm{g}$ yolk, respectively, which show that quail eggs had significantly higher concentration of cholesterol per gram of yolk. On the other hand, lard oil could also induce dyslipidemia due to its high content of long saturated fatty acids (myristic acid, palmitic acid, and stearic acid) and unsaturated fatty acid (oleic acid). Lard oil contains about $26-27 \%$ of palmitic acid, and more than $50 \%$ of it is on the sn-2 position which causes lard oil to be more atherogenic than other oils which is high in palmitic acid (e.g., palm oil). In addition, 
Table 1: Effect of VCO and HVCO on blood TC

\begin{tabular}{|c|c|c|c|c|c|}
\hline \multirow[t]{2}{*}{ Group } & \multicolumn{2}{|l|}{ TC (mg/dl) } & \multirow[t]{2}{*}{ Treatment } & \multirow[t]{2}{*}{ TC after 14 days of treatment } & \multirow[t]{2}{*}{ TC decrease (mg/dl) } \\
\hline & Before induction & After induction & & & \\
\hline 1 & $98.6 \pm 3.9$ & $386.2 \pm 3.8$ & Distilled water & $349.4 \pm 5.6$ & $36.8 \pm 6.5^{\mathrm{a}}$ \\
\hline 3 & $95.6 \pm 5.7$ & $336.6 \pm 8.2$ & VCO 4 ml/kg BW & $226.2 \pm 3.1$ & $110.4 \pm 6.9^{c}$ \\
\hline 4 & $100.4 \pm 3.4$ & $361.6 \pm 5.5$ & VCO 6 ml/kg BW & $201.4 \pm 6.4$ & $160.2 \pm 10.9^{d}$ \\
\hline 5 & $95.8 \pm 5.4$ & $333.8 \pm 8.4$ & HVCO 4 ml/kg BW & $195.4 \pm 6.2$ & $138.4 \pm 8.3^{c, d}$ \\
\hline 6 & $97.8 \pm 5.9$ & $376.8 \pm 7.7$ & HVCO 6 ml/kg BW & $153.6 \pm 4.4$ & $223.2 \pm 5.9^{\mathrm{b}}$ \\
\hline
\end{tabular}

Means \pm SE in each column with different superscript letters differ significantly at $P<0.05$ for $\mathrm{n}=5$ observations. TC: Total cholesterol, VCO: Virgin coconut oil, HVCO: Hydrolyzed virgin coconut oil, SE: Standard error, BW: Body weight

Table 2: Effect of VCO and HVCO on lipid profile in dyslipidemic rats after 14 days of treatment

\begin{tabular}{|c|c|c|c|c|c|}
\hline \multirow[t]{2}{*}{ Treatment } & \multicolumn{5}{|c|}{ Lipid profile (mg/dl) } \\
\hline & TC & TG & HDL-C & LDL-C & VLDL-C \\
\hline Distilled water & $349.4 \pm 5.5^{\mathrm{a}}$ & $174.4 \pm 21.1^{\mathrm{a}}$ & $39.0 \pm 1.7^{\mathrm{a}}$ & $275.5 \pm 4.0^{\mathrm{a}}$ & $34.9 \pm 4.4^{\mathrm{a}}$ \\
\hline Atorvastatin & $129.8 \pm 3.1^{b}$ & $86.8 \pm 8.4^{b, c}$ & $50.2 \pm 2.5^{b}$ & $62.2 \pm 3.2^{\mathrm{b}}$ & $17.4 \pm 1.7^{\mathrm{b}, \mathrm{c}}$ \\
\hline VCO $4 \mathrm{ml} / \mathrm{kg} \mathrm{BB}$ & $226.2 \pm 3.1^{c}$ & $59.2 \pm 2.5^{c}$ & $72.6 \pm 1.1^{c}$ & $141.8 \pm 2.7^{c}$ & $11.8 \pm 0.5^{c}$ \\
\hline VCO 6 ml/kg BB & $201.4 \pm 6.4^{d}$ & $122.0 \pm 12.9^{b}$ & $70.2 \pm 2.4^{c}$ & $106.8 \pm 5.7^{d}$ & $24.4 \pm 2.6^{b}$ \\
\hline HVCO 4 ml/kg BB & $195.4 \pm 6.2^{\mathrm{d}}$ & $70.8 \pm 10.7^{b, c}$ & $77.4 \pm 1.2^{\mathrm{c}}$ & $103.8 \pm 5.6^{d}$ & $14.1 \pm 2.1^{\mathrm{b}, \mathrm{c}}$ \\
\hline HVCO 6 ml/kg BB & $153.6 \pm 4.4^{\mathrm{e}}$ & $81.0 \pm 4.4^{\mathrm{b}, \mathrm{c}}$ & $78.0 \pm 1.2^{c}$ & $59.4 \pm 4.1^{\mathrm{b}}$ & $16.2 \pm 0.9^{b, c}$ \\
\hline
\end{tabular}

Means \pm SE in each column with different superscript letters differs significantly at $P<0.05$ for $\mathrm{n}=5$ observations. TC: Total cholesterol, VCO: Virgin coconut oil, HVCO: Hydrolyzed virgin coconut oil, SE: Standard error, TG: Triglyceride, LDL-C: Low-density lipoprotein cholesterol, HDL-C: High-density lipoprotein cholesterol, VLDL-C: Very low-density lipoprotein cholesterol

Table 3: Effect of VCO and HVCO on AI, TC/HDL-C ratio, and LDL-C/HDL-C ratio on dyslipidemic rats

\begin{tabular}{lll}
\hline Treatment & AI & TC/HDL-C ratio \\
\hline Distilled water & $8.01 \pm 0.32^{\mathrm{a}}$ & LDL-C/HDL-C ratio \\
Atorvastatin & $1.62 \pm 0.16^{\mathrm{b}, \mathrm{c}}$ & $2.00 \pm 0.32^{\mathrm{a}}$ \\
VCO $4 \mathrm{ml} / \mathrm{kg} \mathrm{BW}$ & $2.12 \pm 0.47^{\mathrm{b}}$ & $3.12 \pm 0.17^{\mathrm{b}, \mathrm{c}}$ \\
VCO $6 \mathrm{ml} / \mathrm{kg} \mathrm{BW}$ & $1.88 \pm 0.72^{\mathrm{b}}$ & $2.90 \pm 0.07^{\mathrm{c}}$ \\
HVCO $4 \mathrm{ml} / \mathrm{kg} \mathrm{BW}$ & $1.53 \pm 0.11^{\mathrm{b}, \mathrm{c}}$ & $2.52 \pm 0.12^{\mathrm{b}, \mathrm{c}}$ \\
HVCO $6 \mathrm{ml} / \mathrm{kg} \mathrm{BW}$ & $0.97 \pm 0.69^{\mathrm{c}}$ & $1.98 \pm 0.06^{\mathrm{b}}$ \\
\hline
\end{tabular}

Means \pm SE in each column with different superscript letters differs significantly at $P<0.05$ for $\mathrm{n}=5$ observations. VCO: Virgin coconut oil, HVCO: Hydrolyzed virgin coconut oil, SE: Standard error, LDL-C: Low-density lipoprotein cholesterol, HDL-C: High-density lipoprotein cholesterol, BW: Body weight, AI: Atherogenic index

Table 4: Effect of VCO and HVCO on liver enzymes in dyslipidemic rats

\begin{tabular}{lll}
\hline Treatment & SGOT (U/L) & SGPT (U/L) \\
\hline Distilled water & $192.2 \pm 4.6^{\mathrm{a}}$ & $100.8 \pm 4.8^{\mathrm{a}}$ \\
Atorvastatin & $123.4 \pm 7.3^{\mathrm{b}}$ & $79.4 \pm 2.8^{\mathrm{b}}$ \\
VCO $4 \mathrm{ml} / \mathrm{kg} \mathrm{BW}$ & $122.0 \pm 4.2^{\mathrm{b}}$ & $72.8 \pm 4.5^{\mathrm{b}}$ \\
VCO $6 \mathrm{ml} / \mathrm{kg} \mathrm{BW}$ & $153.0 \pm 4.2^{\mathrm{c}}$ & $68.2 \pm 2.1^{\mathrm{b}, \mathrm{c}}$ \\
HVCO $4 \mathrm{ml} / \mathrm{kg} \mathrm{BW}$ & $95.0 \pm 3.5^{\mathrm{d}}$ & $68.8 \pm 3.7^{\mathrm{b}, \mathrm{c}}$ \\
HVCO $6 \mathrm{ml} / \mathrm{kg} \mathrm{BW}$ & $172.0 \pm 2.3^{\mathrm{c}}$ & $56.6 \pm 1.4^{\mathrm{c}}$ \\
\hline
\end{tabular}

Means \pm SE in each column with different superscript letters differs significantly at $P<0.05$ for $\mathrm{n}=5$ observations. VCO: Virgin coconut oil, HVCO: Hydrolyzed virgin coconut oil, SE: Standard error, SGOT: Serum glutamic oxaloacetic transaminase, SGPT: Serum glutamic pyruvic transaminase

a high content of oleic acid $(\sim 40 \%)$ in lard oil has also been reported to elevate blood TG level [21,24-27].

In the present study, VCO and HVCO significantly decreased blood TC in dyslipidemic rats. The effect of VCO and HVCO to decrease TC level could be due to the unique physicochemical properties of fatty acids contained in VCO and its hydrolyzed form. VCO contains more than $40 \%$ lauric acid which is one of the MCFAs. Oil which composed of MCFA (MCT oil) is metabolized in a different way than LCT oil which composed of LCFA. MCT is hydrolyzed in the mouth and stomach and then metabolized rapidly in the liver to produce energy. MCT does not increase blood TG level, and hence, it does not accumulate in adipose tissue. In addition, MCFA is not converted into lipoprotein which circulates in the blood like its counterpart LFCA $[4,9,26]$.

In this study, the group fed with $6 \mathrm{ml} / \mathrm{kg}$ BW HVCO has the lowest TC and LDL-C levels but the highest HDL-C levels of all groups. However, TG and VLDL-C levels in group fed with $6 \mathrm{ml} / \mathrm{kg}$ BW are higher than the group fed with $4 \mathrm{ml} / \mathrm{kg}$ BW VCO. This may be due to the higher MCFA intake in the group fed with $6 \mathrm{ml} / \mathrm{kg}$ BW HVCO that exceeds caloric needs. Blood lipids are secreted from the intestine to blood circulation as chylomicrons and from the liver to circulation as VLDL. Both lipoproteins transport one molecule of apolipoprotein (apo) which is either B48 or B100. LCFA, such as oleic acid and palmitic acid, generally stimulates apoB secretion and increases intracellular TG, while MCFA inhibits apoB and TG secretion. Although MCFA could decrease TG secretion when consumed in small doses, excessive consumption of MCFA more than the caloric needs could increase de novo lipogenesis. This causes high TG secretion which then increases blood TG [25].

This study also reveals that rats fed with VCO and HVCO have higher TC level than rats fed with atorvastatin does. Although VCO and HVCO increase TC level, they also improve the lipid profile by increasing the HDL-C level. HDL-C is "the good cholesterol" because it has been known as a free radical scavenger which is able to prevent beta-lipoprotein peroxidation. High levels of HDL-C have been considered as a good indicator of a healthy heart. HDL-C below $40 \mathrm{mg} / \mathrm{dl}$ is considered as major risk factor of cardiovascular disease, whereas HDL-C higher than $60 \mathrm{mg} / \mathrm{dl}$ is considered optimal $[7,21,28]$. 
Besides other lipid profile parameters, $\mathrm{AI}$ is also one of the dyslipidemic atherogenic markers which is better than TC to predict the risk of cardiovascular disease. In this study, it is shown that AI in the group fed with $6 \mathrm{ml} / \mathrm{kg}$ BW HVCO does not differ significantly with group fed with atorvastatin. It means that $6 \mathrm{ml} / \mathrm{kg} \mathrm{BW}$ HVCO could lower the risk of cardiovascular disease and has the similar effect as atorvastatin does [29]. Other markers for predicting cardiovascular risk are TC/HDL-C and LDL-C/HDL-C ratios. Both ratios in all groups have significantly lower values than group fed with distilled water. This shows that VCO and HVCO are effective in decreasing the risk of coronary artery disease, especially HVCO with dosage of $6 \mathrm{ml} / \mathrm{kg} \mathrm{BW}$. TC/HDL-C ratio and LDL-C/HDL-C ratio have been known as better predictors for the risk of coronary artery disease rather than TC, LDL-C, or HDL-C alone because the latter would ignore other dyslipidemic component such as TG elevation. Some studies show that the risk of coronary artery disease increases at the value of more than 4 for TC/HDL-C ratio and 2.5 for LDL-C/HDL-C ratio [30,31].

Alteration in liver enzymes is an early marker for the tissue damage by toxic substances or disease conditions. SGOT and SGPT are liver enzymes that occur during hepatic cells damage [10]. In this study, it is shown that rats fed with VCO and HVCO significantly decrease SGOT and SGPT levels in dyslipidemic rats. This suggests that VCO and HVCO are not toxic to the liver

\section{CONCLUSION}

From this study, it can be concluded that VCO and its hydrolyzed form are shown to significantly decrease serum TC, LDL-C, VLDL-C, TG levels, AI, TC/HDL-C ratio, LDL-C/HDL-C ratio, and liver enzymes (SGOT and SGPT) while increase HDL-C level in dyslipidemic rats. HVCO is also shown to have the most effective antidyslipidemic effect.

\section{ACKNOWLEDGMENT}

We gratefully acknowledge financial support from the Ministry of Research, Technology, and Higher Education of the Republic of Indonesia through "PMDSU” Research Grant 2017.

\section{AUTHOR'S CONTRIBUTIONS}

Jansen conceived the study and was in-charge of overall direction and planning. Urip was involved in planning and supervised the work. Denny contributed in the experimental design. Linda performed the experiments, collected and analyzed the data, and wrote the manuscript with input from all authors.

\section{CONFLICTS OF INTEREST}

No conflict of interest is associated with this work.

\section{REFERENCES}

1. Bawalan DD, Chapman KR. Virgin Coconut Oil Production Manual for Micro-and Village-Scale Processing. Bangkok: FAO Regional Office for Asia and the Pacific; 2006

2. Fife B. Virgin Coconut oil: Nature's Miracle Medicine. Colorado Springs: Piccadilly Books, Ltd.; 2006.

3. Enig M. Health and Nutritional Benefits from Coconut Oil: An Important Functional Food for the $21^{\text {st }}$ Century. Ho Chi Min City, Vietnam: AVOC (Asian Vegetable Oils Club) Lauric Oils Symposium; 1996.

4. Man YB, Manaf MA. Medium-chain triacylglycerols. In: Shahidi F, editor. Nutraceutical and Specialty Lipids and their Co-Products. USA: Taylor \& Francis Group, LLC.; 2006. p. 27-56.

5. Bach AC, Babayan VK. Medium-chain triglycerides: An update. Am J Clin Nutr 1982;36:950-62.

6. Fife B. The Coconut Oil Miracle. New York: Penguin Group (USA), Inc.; 2004.

7. Fife B. Health properties of coconut oil. Agro Food Industry Hi Tech 2013;24:5-7.

8. Vala GS, Kapadiya PK. Medicinal benefits of coconut oil. Int J Life Sci
Res 2014;2:124-6.

9. Siddalingaswamy M, Rayaorth A, Khanum F. Anti-diabetic effects of cold and hot extracted virgin coconut oil. J Diabetes Mellitus 2011:1:118-23

10. Mohammed A, Luka CD. Effect of coconut oil, coconut water and palm kernel oil on some biochemical parameters in albino rats. IOSR J Pharm Biol Sci 2013;6:56-9.

11. Akinnuga AM, Jeje SO, Bamidele O, Sunday VE. Dietary consumption of virgin coconut oil ameliorates lipid profiles in diabetic rats. Physiol J 2014;5:Article ID: 495926

12. Kolondam BJ, Pokatong WDR, Tallei TE. Triglyceride and cholesterol level of Wistar rat (Rattus novergicus) after consumption of virgin coconut oil. Biosainstifika 2008;1:35-44. Indonesian.

13. Elsayed HH, Elrahman MK, Emara AH, El-Hafez AA. Compare effect of fatty acid composition (olive, coconut oil and butter) on adipose liver tissue, and serum lipid profile in albino rats. Int J Biochem Biotechnol 2015;1:28-38.

14. Essien NM, Bassey SC, Nna VU, Ofem OE. Comparative effect of chronic consumption of some edible vegetable oils on lipid profile and some haematological parameters in rats. Ann Biol Res 2014;5:16-21.

15. Silalahi J, Permata YM, Putra ED. Antibacterial activity of hydrolyzed virgin coconut oil. Asian J Pharm Clin Res 2014;7:90-4.

16. Elysa E, Harahap U, Silalahi J. Antibacterial activity of enzymatic hydrolysis of virgin coconut oil against salmonella. Int J PharmTech Res 2014;6:589-99.

17. Sihombing NT, Silalahi J, Suryanto D. Antibacterial activity of aqueous garlic (Allium sativum) extracts and virgin coconut oil and their combination against Bacillus cereus ATCC 14579 and Escherichia coli ATCC 8939. Int J ChemTech Res 2014;6:2774-82.

18. Loung FS, Silalahi J, Suryanto D. Antibacterial activity of enzymatic hydrolyzed of virgin coconut oil and palm kernel oil against Staphylococcus aureus, Salmonella thypii and Escherichia coli. Int J PharmTech Res 2014;6:628-33.

19. Margata L, Silalahi J, Harahap U, Satria D. The effect of dietary oils and hydrolyzed coconut oil on minerals absorption in rats. Asian $\mathrm{J}$ Pharm Clin Res 2018;11:185-90.

20. Fatimah F, Gugule S, Layuk P. Pemanfaatan VCO Sebagai Bahan Dasar Produk Pangan Fungsional. Jakarta: Badan Litbang Pertanian; 2009. Available from: http://www.litbang.pertanian.go.id/ks/one/355/ file/pemanfaatan-vco-sebagai-ba.pdf Indonesia. [Last cited on 2015 Aug 07].

21. Hassan S, El-Twab SA, Hetta M, Mahmoud B. Improvement of lipid profile and antioxidant of hypercholesterolemic albino rats by polysaccharides extracted from the green alga Ulva lactuca linnaeus. Saudi J Biol Sci 2011;18:333-40.

22. Hall IH. In: Paoletti R, Kritchevsky D, Holmes WL, editors. Drugs Affecting Lipid Metabolism. Berlin: Springer; 1987. p. 451.

23. Reddy NV, Raj P, Raju G, Anarthe SJ. Antihyperlipidemic activity of Cassia fistula bark using high fat diet induced hyperlipidemia. Int $\mathrm{J}$ Pharm Pharm Sci 2015;7:61-4.

24. Khosla I, Khosla GC. Saturated fats and cardiovascular disease risk: A review. J Clin Prev Cardiol 2017;6:56-9.

25. Marten B, Pfeuffer M, Schrezenmeir J. Medium-chain triglycerides. Int Dairy J 2006;16:1374-82.

26. Scrimgeour C. Chemistry of fatty acids. In: Shahidi F, editor. Bailey's Industrial oil and Fat Products. $6^{\text {th }}$ ed. Hoboken: John Wiley \& Sons, Inc.; 2005. p. 1-43.

27. Silalahi J, Nurbaya S. Composition, distribution and atherogenicity of fatty acid in coconut and palm oils. J Indon Med Assoc 2011;61:453-7.

28. Shelke S, Khairnar A, Rathod V, Kalawane Y, Jagtap A. Review on antihyperlipidemia lipophilic drugs and their novel formulation approaches. Int J Pharm Pharm Sci 2017;9:1-8.

29. Niroumand S, Khajedaluee M, Khadem-Rezaiyan M, Abrishami M, Juya M, Khodaee G, et al. Atherogenic index of plasma (AIP): A marker of cardiovascular disease. Med J Islam Repub Iran 2015;29:240.

30. Nair D, Carrigan TP, Curtin RJ, Popovic ZB, Kuzmiak S, Schoenhagen P, et al. Association of total cholesterol/high-density lipoprotein cholesterol ratio with proximal coronary atherosclerosis detected by multislice computed tomography. Prev Cardiol 2009;12:19-26.

31. Chen QJ, Lai HM, Chen BD, Li XM, Zhai H, He CH, et al. Appropriate LDL-C-to-HDL-C ratio cutoffs for categorization of cardiovascular disease risk factors among Uygur adults in Xinjiang, China. Int $\mathrm{J}$ Environ Res Public Health 2016;13:235. 